Journal of Agricultural Sciences
(Tarim Bilimleri Dergisi)

\title{
Brachytydeus armindae (Momen \& Lundqvist, 2005); a new tydeid record (Acari : Prostigmata), with a revised key to Brachtydeus Thor species of Turkey
}

\author{
Sultan ÇOBANOĞLUa $\mathbb{D}$, Ayşe YEŞiLAYER ${ }^{\mathrm{b}} \mathbb{D}$, Ayhan ÖĞRETENc ${ }^{\mathbb{D}}$

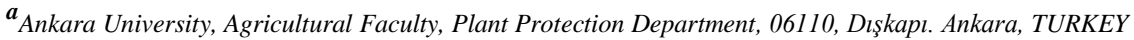

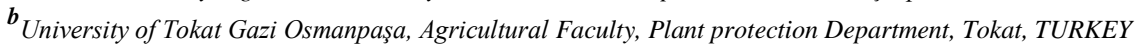

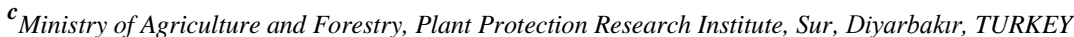

ARTICLE INFO

Research Article

Corresponding Author: Sultan ÇOBANOĞLU, E-mail: scobanoglu@ankara.edu.tr

Received: 19 June 2019 / Revised: 07 September 2019 / Accepted: 26 September 2019 / Online: 18 January 2021

\section{ABSTRACT}

Tydeoidea species (Acari: Prostigmata) are little and soft-bodied creatures and globally distributed. In the world, Tydeidae comprises 328 species in 30 genera, and Brachytydeus has the most number of species with 200. Tydeoidea presented by 23 species while Brachytydeus comprises eight species, gathered in orchards and shrub trees in Turkey. Brachytydeus armindae (Momen \& Lundqvist 2005) (Acari: Tydeidae), found in association with Thuja orientalis L. (Cupressaceae) trees and stored wheat, is reported as a new species of tydeid fauna of Turkey. Distribution and host details of $B$. armindae are provided along with descriptive photos and illustrations. An updated key to Brachytydeus Thor species is given.

Keywords: Mites; Tydeidae; Brachytydeus armindae; stored products; Thuja

(C) Ankara University, Faculty of Agriculture

\section{Introduction}

Tydeoid mites (Acari: Prostigmata) are little and soft-bodied creatures with globally scattering. They live soil and herbaceous plants to relationships with invertebrates, slugs and backboned. They are mostly herbivore, mycophagist, pollen feeders, parasites on insects or decaying consumers. They are capable of surviving in regions with extreme climates like from the North to South Pole ecosystems (Krantz \& Walter 2009). Tydeidae comprises 328 species in 30 genera, and Brachytydeus has a high amount of species with 200, subsequently Tydeus Koch have 50 species (Da-Silva et al. 2016).

Çobanoğlu \& Kazmierski (1999), reported 4 Brachytydeus species collected form orchards and shrubs, Brachytydeus amica (Kazmierski 1998), B. ferula Baker 1944, B. pulchra (Oudemans 1929); B. reticulata (Oudemans 1928) were mentioned in Thrace region, and all around Turkey. Following that B. livshitzi (Kuznetzov 1974), B. obnoxia (Kuznetzov et Zapletina 1972, in Livshitz et al. 1972) and B. paraobliqua (Panou \& Emmanuel 1996) were mentioned from hazelnut orchards in Northern part of country (Ozman-Sullivan et al. 2005; Akyazı et al. 2017). Brachytydeus maga (Kuznetzov \& Livshitz 1973), Tydeus kochi (Oudemans1928), Tydeus californicus (Banks 1904) and Tydeus plumosus Karg 1975 were mentioned recently for Tydeidae family of Turkey which are found in association with stored wheat, vegetables and ornamental plants (Kumral \& Çobanoğlu 2016; Ueckermann et al. 2019; Çobanoğlu et al. 2020). Till date, eight species were reported under Brachytydeus Thor (Ueckerman et al. 2019). This paper aims to report the occurrence of Brachytydeus armindae in Turkey and present a revised key for Brachytydeus genus.

\section{Material and Methods}

The mites were collected randomly from Thuja orientalis L. (Cupressaceae) trees in Istanbul and different storage facilities of stored wheat bran in Diyarbakir and Mardin during 2013-2014.

In storages, wheat seed and debris were gathered from the different level of the bulk with a split probe, depending on the size of the pile. Finally, they were mixed and taken into half $\mathrm{kg}$ amounts. The plant samples were taken by randomly to the shoots and green parts of the Thuja trees, in 2008. 
The mite specimens were observed under a stereomicroscope and they were pulled out by a Berlese funnel. The collected mite specimen was preserved in $70 \%$ ethyl-alcohol. Samples were clarified with lactophenol solution, and microscopic preparations were made at Hoyer's medium. Mounted mites were detected by a phase-contrast Leica microscope and measured by a Leica software image analysing system.

The taxonomical characteristics measurements were made in micrometres $(\mu \mathrm{m})$. The gnathosoma was measured from the base of the chelicerae to the tip. Palpus; from femur to tip of tarsus, the length of the body measurement was considered from the base of the chelicerae to posterior end of the body. The width of the body was measured at the level of setae (c2). Setae were measured from the setal base to their apex and the legs from trochanter to the end of the tarsal claw. Both setae and solenidia counts of the leg segments were considered and solenidia indicated in brackets.

The following publications were consulted for the identification of the species: Momen \& Lundqvist (2005), Da- Silva et al. (2016) and Ueckermann et al. (2019). The voucher specimen were kept among the mite collection at Ankara University, Plant Protection Department.

\section{Results and Discussion}

Tydeiodea Kramer 1877

Tydeidae Kramer 1877

Brachytydeus Thor 1931

Brachytydeus armindae (Momen \& Lundqvist 2005); Da -Silva et al. (2016): 10.

Tydeus armindae Momen \& Lundqvist 2005: 229

Diagnosis: Opisthosoma striated transversal between setae $d l$ to behind setae $f l$; some of the dorsal setae length, longer than half distance next behind.

Female $(\mathrm{n}=2)$

Dorsum (Figures 1-13, 15). Idiosomal length 305, width 218, with sparsely serrated dorsal setae, trichobothria (sci) filiform, slender and smooth. Setae $f 2, h 1, h 2$ and $p s 1$ longer than the other setae and blunt shaped. Dorsum simply striated, lack of reticulation. Prodorsum striated longitudinally, on opisthosoma transversal striation between setae $\mathrm{c} 1$ and $\mathrm{d}$.

Dorsal setae lengths of: vi 17-23, ve 13-14, sci 45, sce 16, cl 14-15, c2 15-24, d 15-16, e 16, fl 20-24,f2 20-27, h1 21-25, h2 22- 26, psl 26; sci-sce 39; hl-h2 24; h2-c2 46; cl-cl 42; d-d 28; d-cl 67 (Figs 1-3; 5-7).

Venter (Figures 14, 16). Distance of setae $3 a$ and $4 a$ longitudinally striated. Genital cleft flanked by 6 pairs of short setae (gl-g6) (9-5) and 4 pairs agential setae (ag1-ag4) (11-12). Anal opening surrounded by anal setae ps2 (11-17).

Gnathosoma (Figures 4, 8-9). Palp 71-81 long. The setal formula of palp (genua-tarsus) 2-2-6 ( $\omega$, not included in count), seta $(d)$ forked distally. Palp tibial claw as long as palp tarsi.

Legs (Figs 10-14). Legs: I 170, II 132, III 140, IV158. Leg segments setal formulae: Tarsi 8( $\omega)-6(\omega)-5-5$, tibiae 3(+1)-2-22, genua 3-2-1-1, femora 3-3-2-1, trochanters 1-0-1-0. Solenidia on tarsi II (3) shorter than solenidia on tarsi I (8-11). All tarsi include claws and empodium with a well-developed claw. Seta $(\kappa)$ on tibia I is forked.

Material Examined: (1 9 ), (02.03.2008) Thuja orientalis L. (Cupressaceae), Kuleli-Istanbul; (4058'46.2"N; 2903'19.8"E); (1ㅇ), (03-07-2014), wheat bran, Diyarbakır (37 5'65.066"N: 40¹'40.041"E).

Distribution: It was reported from Sweden on lichens in mosses (Momen \& Lundqvist 2005; Da-Silva et al. 2016) and Turkey with this study.

Remarks. Brachytydeus armindae specimens from Turkey is similar to the original description in all taxonomical characteristics. This species is separated easily from the other closest species by thick and blunt setae of $f 2, h 2$ and $P s 2$. Brachytydeus armindae is a new record for the Tydeiidae fauna of Turkey. 


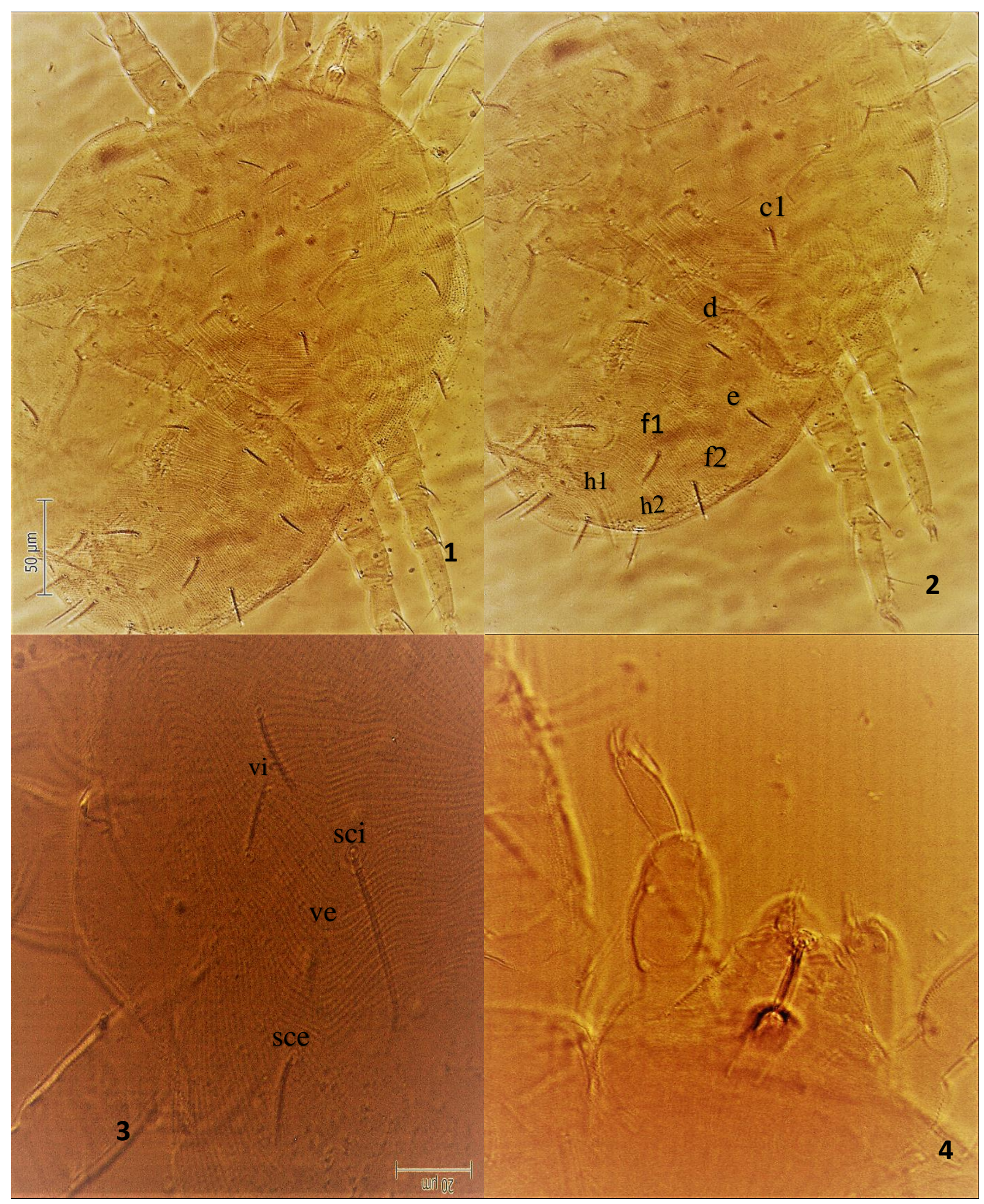

Figures 1-4. Brachytydeus armindae (Momen \& Lundqvist) (Female), 1. General view, 2. Idiosoma, 3. Prodorsum, 4. Chelicera. 


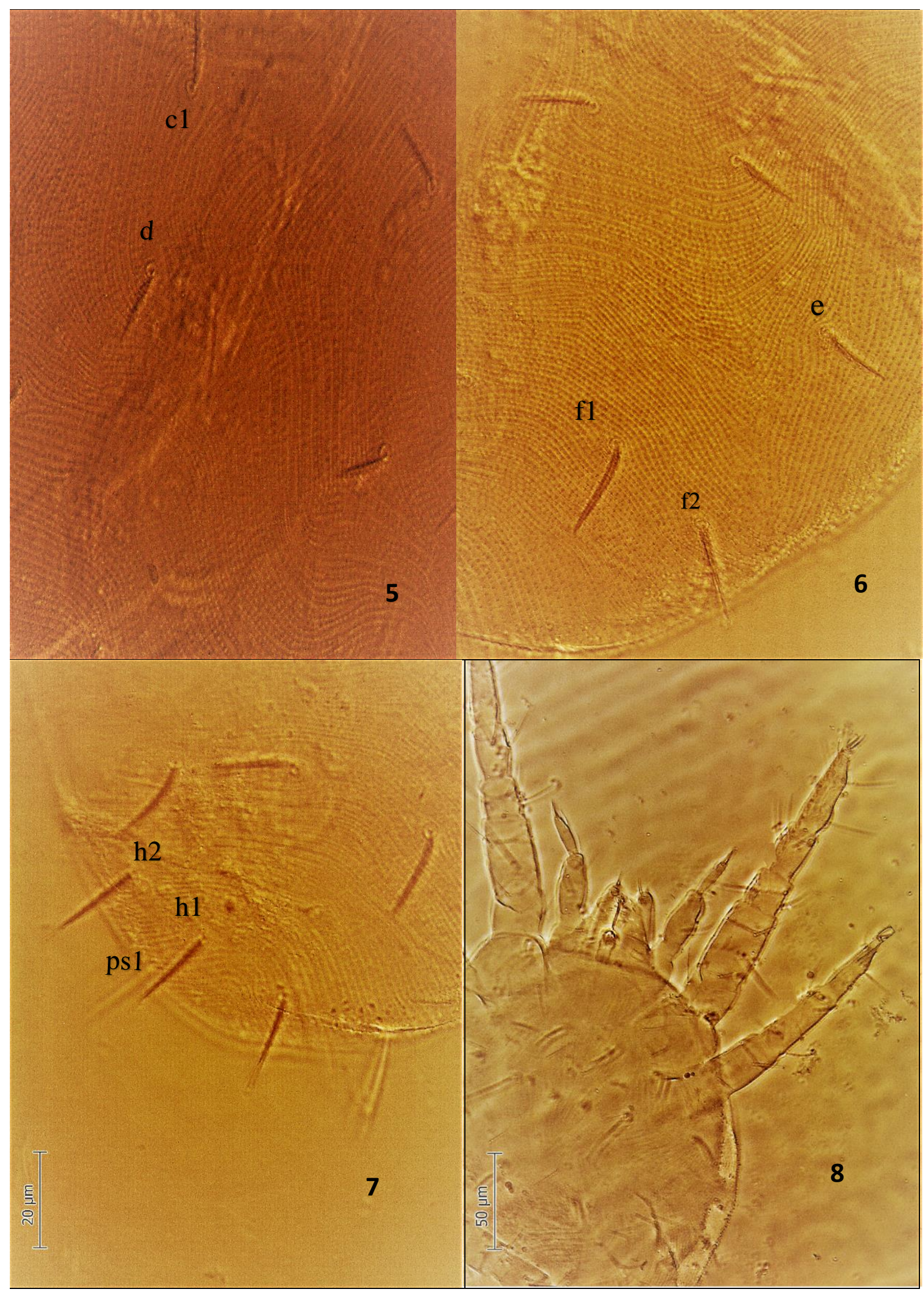

Figures 5-8. Brachytydeus armindae (Momen \& Lundqvist) (Female), 5. Dorsal stetae (c1-d), 6. Dorsal setae $(e, f 1, f 2), 7$. Opisthosomal setae $(h 1-h 3, p s 1), 8$. Gnathosoma. 


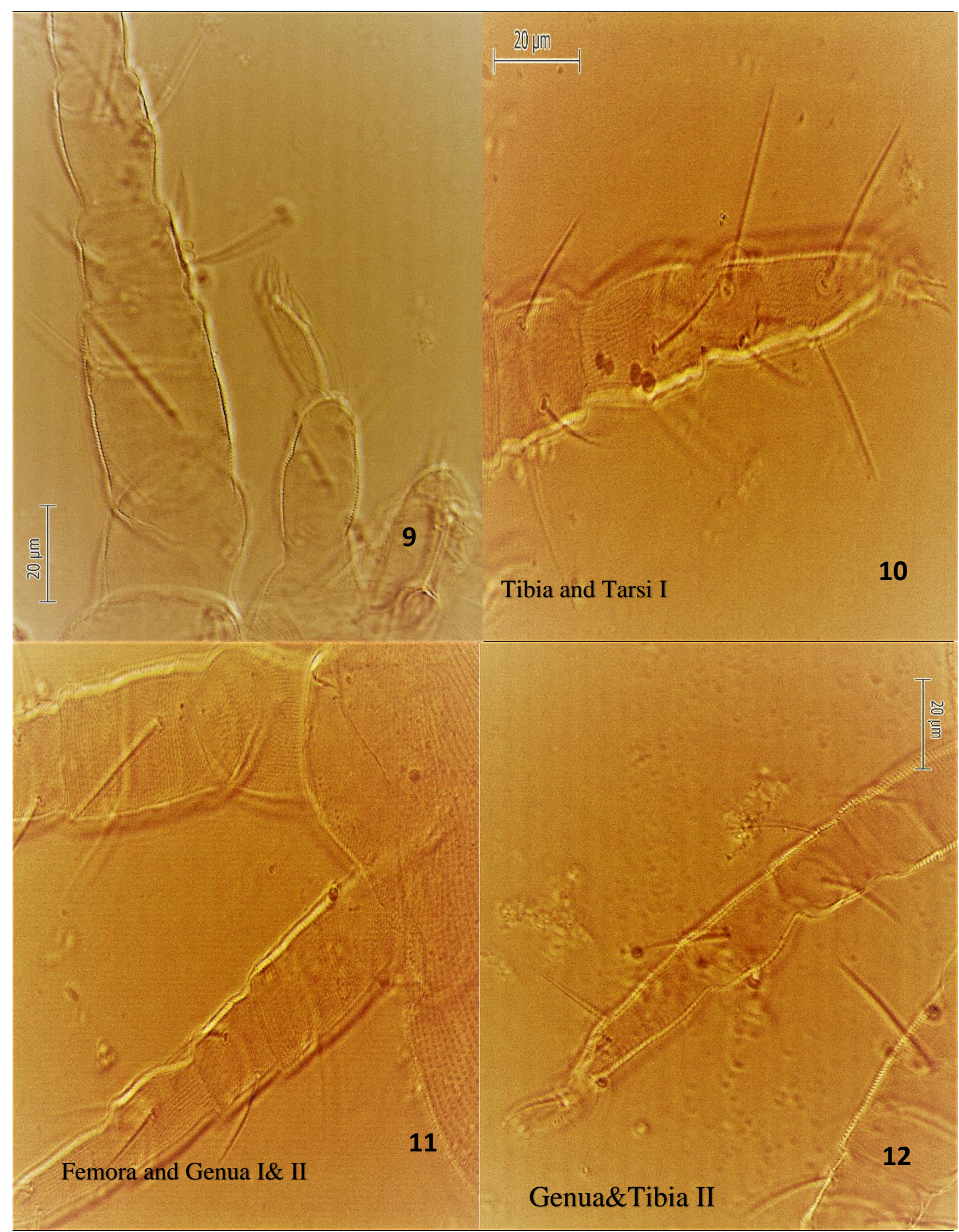

Figures 9-12. Brachytydeus armindae (Momen \& Lundqvist) (Female), 9. Palp, 10. Tibia and Tarsi I, 11. Femora and Genua I \& II, 12. Genua \& Tibia II. 


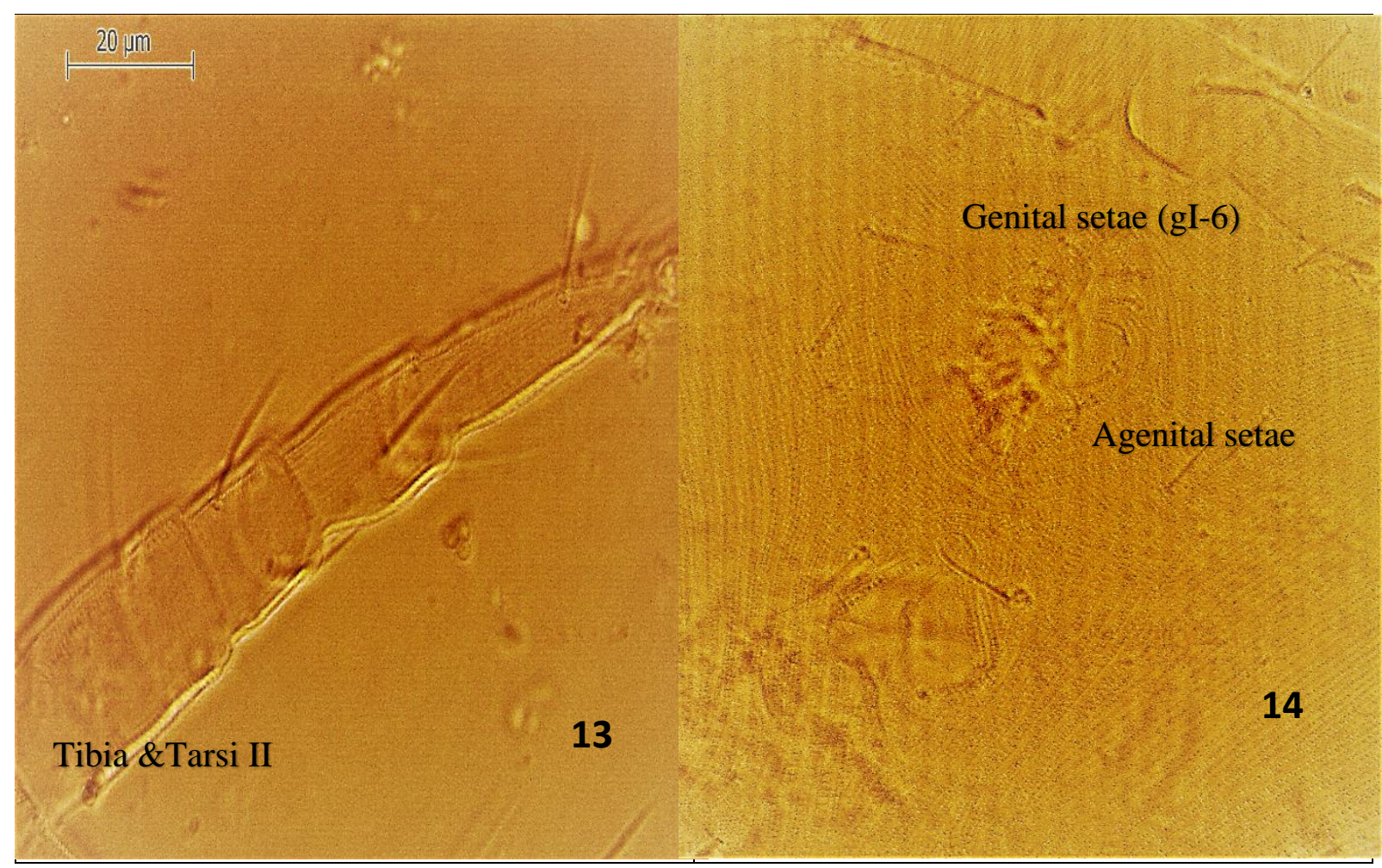

Figures 3-14. Brachytydeus armindae (Momen \& Lundqvist) (Female), 13. Tibia \& Tibia II, 14. Ventral view.

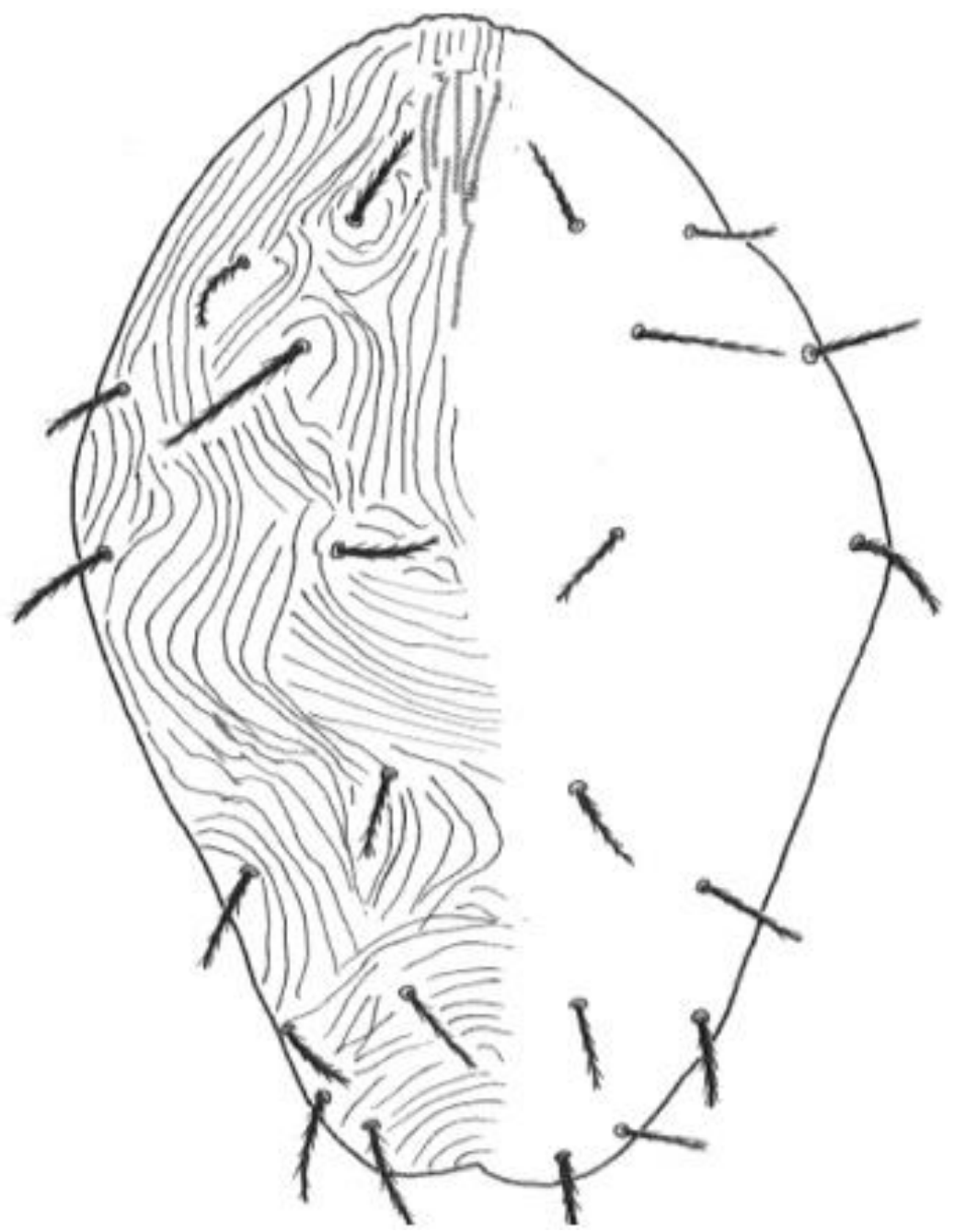

Figure 15- Brachytydeus armindae (Momen \& Lundqvist) (Female), dorsal view. 


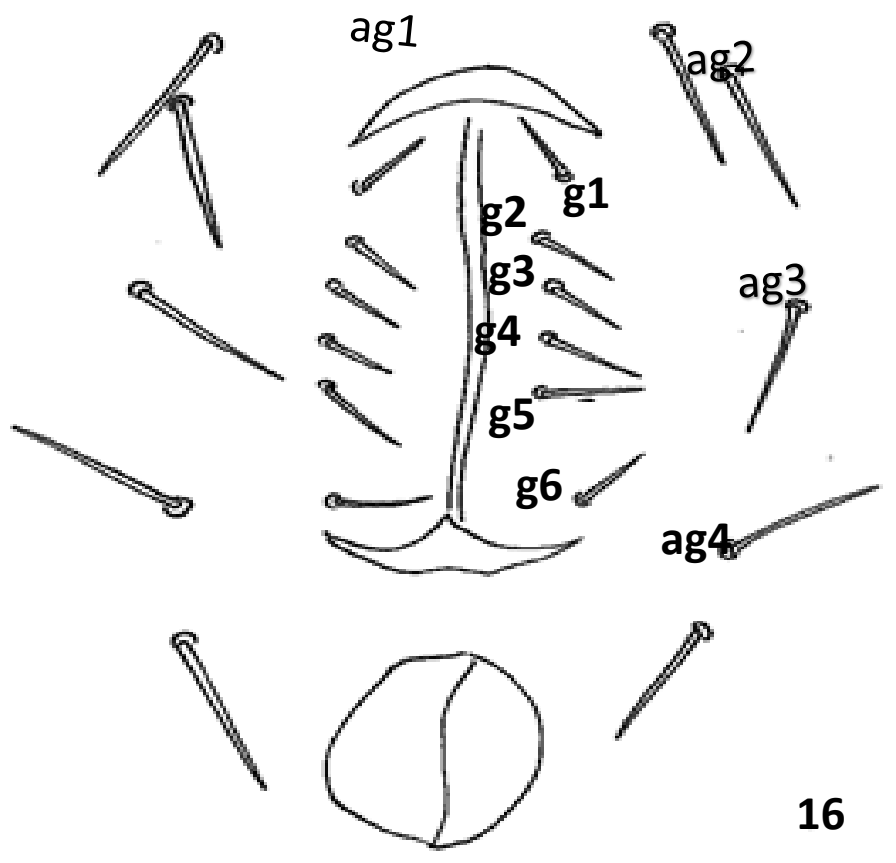

Figure 16- Brachytydeus armindae (Momen \& Lundqvist) (Female), female genital area.

Key to the Brachytydeus Thor, species of Turkey, Females (Based on Ueckermann et al. 2019)

1 -Two setae on femur III Brachytydeus Thor.

-One seta on femur III. Tydeus Koch

2 -Dorsum with completely reticulated. 3

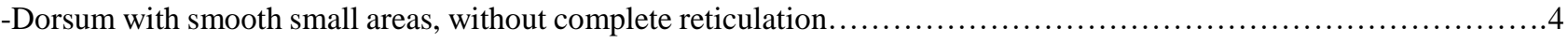

3 -Dorsum with setae various-shaped caudally, at most half length of the distance between afterwards

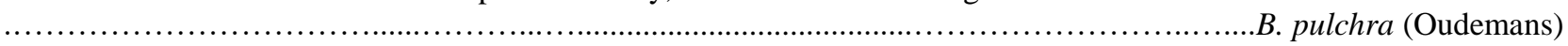

-Dorsum with rod like setae, longer than half the distances or longer than distances between afterwards. B. reticulata (Oudemans)

4 -Hysterosoma striated with vertically between setae $d l$ or extending to $f 1$ 5

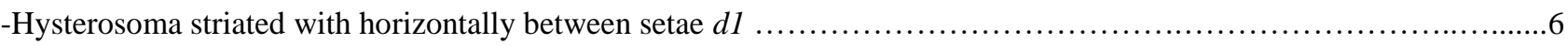

5 -Setae $h 1-2$ and $p s l$ dull edge at end

B. amica (Kazmierski) (f2 apically sharped). B. ferula (Baker) ( $\mathrm{f}_{2}$ obtuse at the tip) -Hysterosomal setae, short and hairy apart from sci, B. maga (Kuznetzov)

6 -Dorsum of idiosoma with various little web like areas B. livshitzi (Kuznetzov)

-Dorsum of idiosoma lack of web like areas

7 -Hysterosomal setae mostly rounded edge with $f 1, f 2, h 1, h 2$ and $p s 1$ clavate;...

B. paraobliqua (Panou \& Emmanouel)

-Hysterosomal setae mostly short in size, similar shape or some of the longer of blunt shaped. .88

8 -Hysterosomal setae short and similar in shape

B. obnoxia (Kuznetzov \& Zapletina)

-Some dorsal setae $(f 2 h 1, h 2, p s l)$ longer than others and blunt shaped distally. Prodorsal setae moderately notched B. armindae (Momen \& Lundqvist

\section{Acknowledgements}

This publication has formed a part of the PhD study of Ayhan Öğreten. We thanks Prof. Mohammad Khanjani (Bu-Ali Sina University, College of Agriculture, Hamedan, Iran) and his colleagues for confirmation of the identification of species. We wish to thanks Dr Sreerama Kumar Prakya (Principal Scientist (Plant Pathology; India) early reading of this manuscript. 


\section{References}

Akyazı R, Ueckermann E A, Akyol D \& Soysal M (2017). Distribution of mite species (Acari) on persimmon trees in Turkey (Ordu), with one newly recorded mite species and one re-described species. International Journal of Acarology 43: 563-581 http://dx.doi.org/10.1080/01647954.2017.1373149

Baker E W (1944). Tideidos Mexicanos (Acarina, Tydeidae). Revista de la Sociedad Mexicana de Historia Natural 5: 73-82

Banks N (1904). Four new species of injurious mites. Journal of the New York Entomological Society 12: 53-56

Çobanoğlu S \& Kazmierski A (1999). Tydeidae and Stigmaeidae (Acari: Prostigmata) from orchards, trees and shrubs in Turkey. Biological Bulletin of Poznan 36: 71-82

Çobanoğlu S, Akçakoyunluoğlu K \& Çalmaşur Ö (2020). Mite Diversity (Acari) from Ornamental Plants in Erzurum in Turkey. Journal of Agricultural Sciences (Tartm Bilimleri Dergisi) 26: 236-245 DOI: 10.15832/ankutbd.518260

Da- Silva G L, Metzelthin M H, Da Silva O S \& Ferla N J (2016). Catalogue of the mite family Tydeidae (Acari: Prostigmata) with the world key to the species. Zootaxa 4135: 1-68 http://doi.org/10.11646/zootaxa.4135.1.1

Karg W (1975). Zur Kenntnis der Tydeiden (Acarina: Trombidiformes) aus Apfelanlagen. Zoolgischer Anzeiger Jena 194: 91-110

Kazmierski A (1998). Tydeinae of the world: generic relationships, new and redescribed taxa and keys to all species. A revision of the subfamilies Pretydeinae and Tydeinae (Acari: Actinedida: Tydeidae)-part IV. Acta Zoologica Cracoviensia Krakow 41 (2): $283-455$

Kramer P (1877). Tydeidae. Archiv für Naturgeschichte 43:232-246

Krantz G W \& Walter D E (2009). A manual of Acarology. Third Edition. Texas Technical University Press p. 807

Kumral N A \& Çobanoğlu S (2016). The Mite (Acari) Biodiversity and Population Fluctuation of Predominant Species in Eggplant. Journal of Agricultural Sciences (Tartm Bilimleri Dergisi) 22: 261-274 DOI: 10.1501/Tarimbil_0000001386

Kuznetzov, N.N. (1974) A contribution to the fauna of the family Tydeidae (Acariformes) of the Central Chernozem District. Zoologicheskii Zhurnal 53: 1092-1093 [In Russian]

Kuznetzov N N \& Livshitz I Z (1973). Three new species of the genus Paralorryia (Acariformes, Tydeidae) from the Nikitsky Botanical Gardens. Zoologicheskiy Zhurnal 52: 604-606 [In Russian]

Livshitz I Z, Kuznetzov N N \& Zapletina V P (1972) New species of the family Tydeidae (Acariformes) from Crimea and Azerbaijan. Zoologicheskii Zhurnal 51: 1578-1580

Momen F M \& Lundqvist L (2005). The genera Metalorryia and Tydeus (Acari: Prostigmata: Tydeidae), new and unrecorded species from south Sweden. International Journal of Acarology 31: 225-236 http://dx.doi.org/10.1080/01647950508684425

Oudemans A C (1928). Acarologische Aantekeningen 94. Entomologische Berichten 7: 374-382

Oudemans A C (1929). Acarologische Aantekeningen 95. Entomologische Berichten 7: 393-399

Ozman-Sullivan S K, Kazmierski A \& Çobanoğlu S (2005). Alycina and Eupodina mites in hazelnut orchards in Turkey. Proc. VIth Intl. Congress on Hazelnut (Eds. J. Tous, M. Rovira \& A. Romero). Acta Horticulturae 686: 401-406

Panou H N \& Emmanouel N G (1996) Two new species of Lorryia (Acari: Tydeidae) from Greece. Entomologische Mitteilungen aus dem Zoologischen Museum Hamburg 12: 91-103

Thor S (1931). Norwegische Tydeidae I-VII, mit Kennzeichnung vier neuer gattungen. Zoologischer Anzeiger 94: 89-104

Ueckermann E A, Çobanoğlu S \& Öğreten A 2019. Re-description of two new tydeid records (Acari: Trombidiformes) with a key to Tydoidea species of Turkey. Systematic and Applied Acarology 24: 497-507. http://doi.org/10.11158/saa.24.3.13 497 